\title{
Positioning of the NOR-Bearing Chromosomes in Relation to Nucleoli in Daughter Cells after Mitosis
}

\author{
M. KALMÁROVÁ, E. SMIRNOV, L. KOVÁČIK, A. POPOV, I. RAŠKA \\ Institute of Cellular Biology and Pathology, First Faculty of Medicine, Charles University in \\ Prague, and Department of Cell Biology, Institute of Physiology, Academy of Sciences of the \\ Czech Republic, v.v.i., Prague, Czech Republic
}

Received October 18, 2007

Accepted December 4, 2007

\begin{abstract}
Summary
It is known that chromosomes occupy non-random positions in the cell nucleus. However, it is not clear to what extent their nuclear positions, together with their neighborhood, are conserved in daughter cells. To address specific aspects of this problem, we used the model of the chromosomes carrying ribosomal genes that are organized in clusters termed Nucleolus Organizer Regions (NORs). We compared the association of chosen NOR-bearing chromosomes (NOR-chromosomes) with nucleoli, as well as the numbers of nucleoli, in the pairs of daughter cells, and established how frequently the daughter cells had equal numbers of the homologs of certain NORchromosomes associated with individual nucleoli. The daughter cells typically had different numbers of nucleoli. At the same time, using immuno-FISH with probes for chromosomes 14 and 15 in HeLa cells, we found that the cell pairs with identical combinations appeared significantly more frequently than predicted by the random model. Thus, although the total number of chromosomes associated with nucleoli is variable, our data indicate that the position of the NOR-bearing chromosomes in relation to nucleoli is partly conserved through mitosis.
\end{abstract}

\section{Key words}

Chromosome positioning • Nucleoli • NORs • Daughter cells

\section{Corresponding author}

M. Kalmárová, Institute of Cellular Biology and Pathology, First Faculty of Medicine, Charles University, Albertov 4, 12801 Prague 2, Czech Republic. Fax: $+(420) 224917418$. E-mail: mfial@If1.cuni.cz

\section{Introduction}

Chromosomes are not randomly arranged in the vertebrate cell nucleus (Cremer and Cremer 2001, 2006,
Foster and Bridger 2005, Parada and Misteli 2002, Pederson 2004). However, it is not clear to what extent their nuclear positions, together with their neighborhoods, are conserved in daughter cells (Bickmore and Chubb 2003). Using similar experimental approaches, the results of recent studies argued that the chromosomes were arranged similarly in maternal and daughter cells (Essers et al. 2005, Gerlich et al. 2003), or that positions of chromosomes in daughter nuclei were conserved only partly and in most cases largely differed from the positions seen in mother cell nuclei (Walter et al. 2003).

To address specific aspects of this problem, we used the model of the chromosomes carrying ribosomal genes. These genes are organized in clusters termed Nucleolus Organizer Regions (NORs) (McClintock 1934, Busch and Smetana 1970). Nucleoli disintegrate during mitosis, and at the beginning of the next $G_{1}$ phase NORs from more than one chromosome cluster and participate in the formation of a given nucleolus (Raška, 2003, Raška et al. 2004). In the middle of $\mathrm{G}_{1}$ phase the position of chromosomes and the number of nucleoli in the nucleus are already stable and do not change significantly until the end of the interphase (Walter et al. 2003, Cremer and Cremer 2006, Foster and Bridger 2005, Parada and Misteli 2002). We therefore selected pairs of daughter cells in this period of the cell cycle, and compared the association of chosen NOR-bearing chromosomes (NORchromosomes) with nucleoli in the pairs of daughter cells from the human derived HeLa cell line. We thus did not investigate the maternal cell with regard to the daughter cells, but focused on the similarity between the two daughter cells.

The aim of our study was to establish how 
frequently the daughter cells had equal numbers of the homologs of certain NOR-chromosomes associated with individual nucleoli. Since the conservation of the chromosome positioning in relation to nucleoli depends on the number of nucleoli per nucleus, we also compared the numbers of nucleoli in the two daughter cells. It should be mentioned that the approach used here did not allow us discriminate between the individual homologs of the chromosomes associated with each nucleolus.

\section{Methods}

HeLa cells were cultivated in flasks at $37^{\circ} \mathrm{C}$ in Dulbecco modified Eagle's medium (DMEM, Sigma, USA) containing $10 \%$ fetal calf serum, $1 \%$ glutamine, $0.1 \%$ gentamycin, and $0.85 \mathrm{~g} / 1 \mathrm{NaHCO}_{3}$ in atmosphere supplemented with $5 \% \mathrm{CO}_{2}$. The preparations of the couples of postmitotic cells were obtained by shaking and seeding mitotic cells on the glass coverslips. In such procedure we could get sufficient numbers of clearly distinguished pairs of the postmitotic daughter cells. In vivo time-lapse observations encompassing a period from mitosis to mid $G_{1}$ showed that the cells of different pairs did not mix during this period (data not shown).

Commercial $\mathrm{Cy} 3-$ and FITC-labeled whole chromosome painting probes for human chromosomes $13,14,15,21$ and 22, were supplied ready to use in hybridization mixture (Appligene Oncor, USA). Primary monoclonal antibody against mouse fibrillarin (clone 17C12), kindly donated by Kenneth M. Pollard (Scripps Research Institute, La Jolla, CA), was used for immunovisualization of nucleoli. Secondary anti-mouse antibodies (Jackson ImmunoResearch Laboratories) were conjugated with $\mathrm{Cy} 3$ or FITC.

The combined detection of fibrillarin and in situ hybridization (immuno-FISH) was performed according to Pliss et al. (2005). After fibrillarin imunolabeling the cells were postfixed with methanol/acetic acid (3:1) overnight at $-20{ }^{\circ} \mathrm{C}$, then the regular FISH procedure followed (Pliss et al. 2005), except the post hybridization washing. Namely, the cells were washed in $50 \%$ formamide in $2 \mathrm{xSSC}, \mathrm{pH} 7$, for $15 \mathrm{~min}$ at $43{ }^{\circ} \mathrm{C}$, in $0.1 \%$ Tween-20/2xSSC for $8 \mathrm{~min}$ at $43^{\circ} \mathrm{C}$; in $0.1 \%$ Igepal (ICN Biomedicals, Inc) / 4xSSC for $3 \times 4$ min at $37^{\circ} \mathrm{C}$, in PBS $3 \times 3 \mathrm{~min}$ at RT (Harničarová et al. 2006). Coverslips were mounted in Mowiol supplemented with DABCO and viewed using Olympus AX70 Provis equipped with the Photometrics CCD camera.

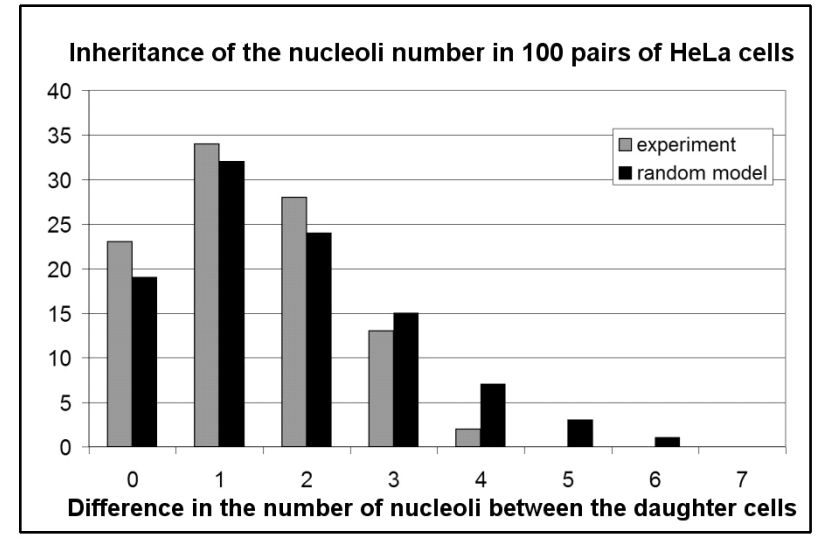

Fig. 1. Differences in the nucleoli number between the daughter HeLa cells. The number of nucleoli in the daughter cells most frequently differed by one (gray bars). Only in $23 \%$ of cell pairs, the number of nucleoli was identical. Observed differences in the number of nucleoli between the daughter cells closely corresponded to those in the random model (black bars).

\section{Results}

Nuclei of HeLa cells contained usually 2-5 nucleoli, with average number $4.03 \pm 0.12$ (Kalmárová et al. 2007). The number of nucleoli were most frequently different in the daughter cells (Fig. 1). Specifically, in $77 \%$ cases, the daughter cells contained different numbers of nucleoli. We additionally compared our data with a random model. In this model the appearance of the pairs of daughter cells with $i$ and $j$ nucleoli was calculated as product of the experimentally found frequencies of the cells with $i$ and $j$ nucleoli. Comparing the incidence of the nucleoli in 100 pairs of daughter cells, we found a close correspondence with the random model (Fig. 1).

Next we visualized chromosomes 14 and 15, performing hybridization with $\mathrm{Cy} 3$ - and FITC-labeled probes, in combination with immunolabeling of nucleoli using antibody against fibrillarin. The HeLa cells typically possess four homologs of chromosome 15 and three homologs of chromosome 14. Different numbers of these chromosomes can be associated with each nucleolus (Kalmárová et al. 2007). Accordingly, different cells may have different combinations of the nucleolar association. In case of the chromosome 15, all four homologs are nucleoli-associated (Kalmárová et al. 2007, Smirnov et al. 2006). For instance, five combinations are possible in cells with four nucleoli (Fig. 2). In one extreme situation, all four chromosomes are associated with one nucleolus. In the other extreme situation, there is one chromosome associated with each of the nucleoli (Fig. 3, A-C). In case of the chromosome 14, not all homologs are associated 


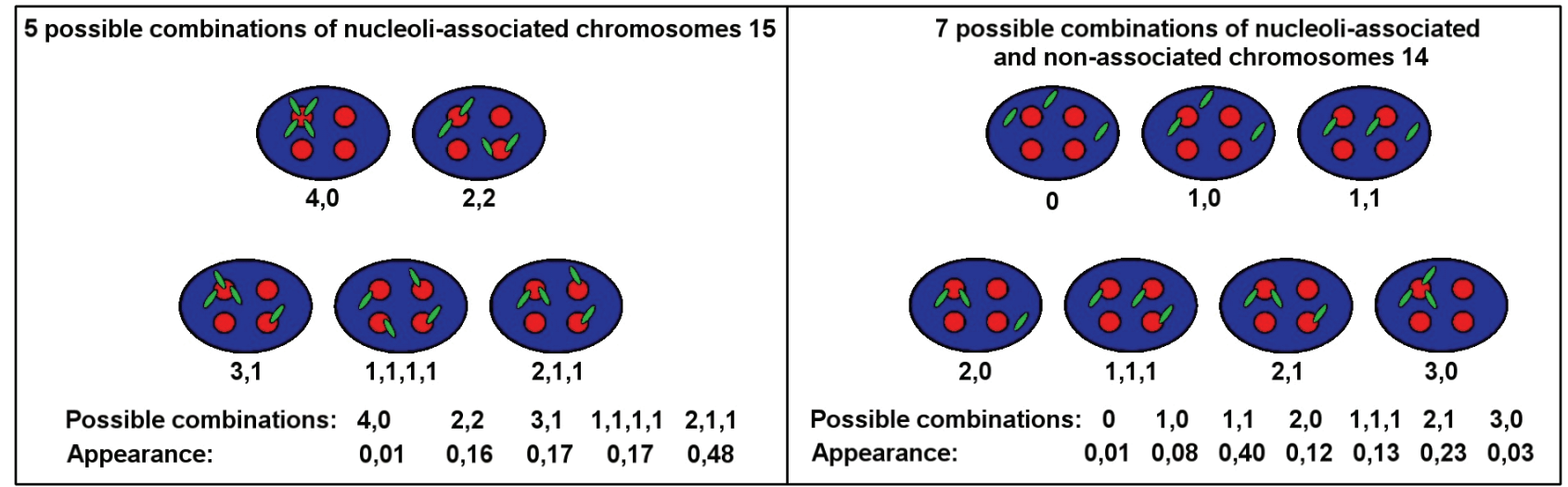

Fig. 2. Scheme depicting relations between nucleoli (red) and chromosomes 14 and 15 (green) in the cell nucleus (blue): all possible combinations of the nucleolar associations for the case of cells with four nucleoli are shown. All chromosomes 15 are associated with nucleoli, but some chromosomes 14 are not nucleoli-associated.
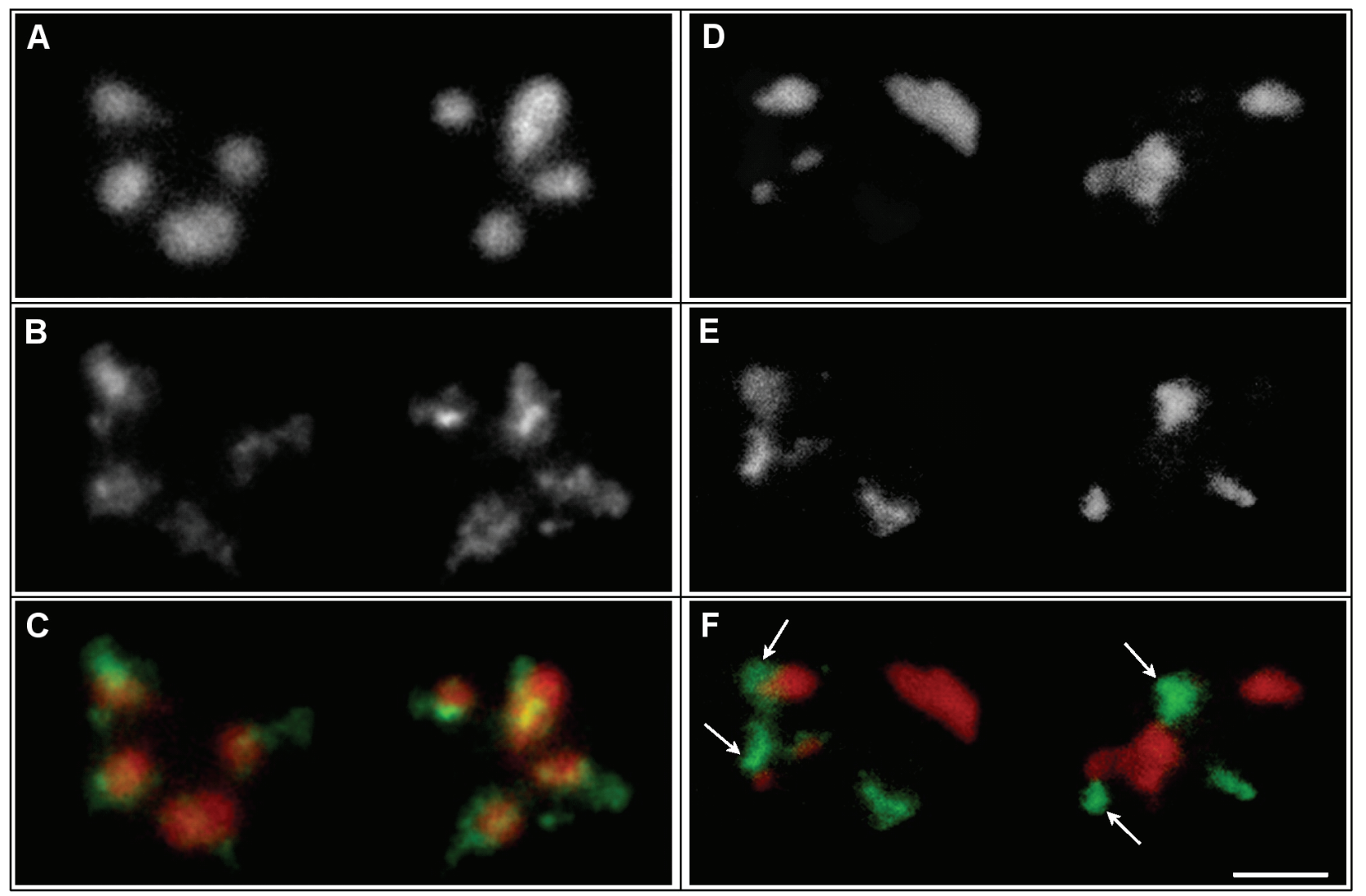

Fig. 3. Combinations of positions of chromosomes 14 and 15 in relation to nucleoli as compared in daughter HeLa cells. FISH signal with the specific probes for chromosomes 14 and 15 (B, E; green in $C, F)$ in a couple of interphase daughter cells. Immunocytochemistry with fibrillarin was used to visualize nucleoli (A, D; red in C, F). In the chosen example of chromosome 15 (A, B, C), all four homologs are associated with nucleoli, deeply penetrating into them, which is typical for the chromosome 15 (Kalmárová et al. 2007). This case corresponds to the combination $(1,1,1,1)$ in Fig. 2. In the chosen example of chromosome 14 (D, E, F), two chromosome homologs are nucleoli associated (arrows in F), and one is separated from the nucleoli. This case corresponds to the combination $(1,1)$ in Fig. 2. Bar: $10 \mu \mathrm{m}$.

with nucleoli (Fig. 3, D-F) (Kalmárová et al. 2007, Smirnov et al. 2006), which increases the number of possible combinations to seven (Fig. 2).

Comparing these combinations in the daughter cells, we surprisingly found that in $50 \%$ of cell pairs, for both chromosome 14 and chromosome 15, the combinations were identical (Table 1). To evaluate these data, we used a random pairing model in which appearance of the pairs of daughter cells with combinations $i$ and $j$ was calculated as product of the 
Table 1. Similarity of the position of the NOR-bearing chromosomes with respect to nucleoli in the daughter cells. In $50 \%$ of the cell pairs the combinations are identical for both chromosome 14 and chromosome 15, which significantly exceeds the values predicted by the random model.

\begin{tabular}{lccc}
$\begin{array}{l}\text { Chromo- } \\
\text { somes }\end{array}$ & \multicolumn{2}{c}{ Frequency of symmetrical distribution } \\
& Experiment & Random model & n \\
\hline 15 & 0.50 & 0.32 & 160 \\
14 & 0.50 & 0.25 & 100 \\
\hline
\end{tabular}

experimentally found frequencies of the cells with the combinations $i$ and $j$. The pairs with identical combinations appeared with significantly higher frequency in the experiment $(50 \%)$ than in the random model (32\% for chromosome 15 and $25 \%$ for chromosome 14) (Table 1).

Additionally, in the case of chromosome 14 we observed a significant symmetry in the distribution of the non-associated chromosomes after mitosis: in $62 \%$ cases the daughter cells had equal number of such chromosomes, while the random model predicted only $44 \%$.

\section{Discussion}

In this study we observed that the daughter cells typically had different numbers of nucleoli (Fig.
1). Such an asymmetry, observed also by other authors (see e.g. Leung et al. 2004), is not entirely compatible with the claim that global chromosome positions are basically heritable through mitosis (Gerlich et al. 2003). In this respect, our results are in harmony with the work of Walter et al. (2003), according to which there is only a limited similarity in chromosome positioning between the daughter cells. However, we found that chromosomes 14 and 15, showed a similar pattern of nucleolar associations more frequently than predicted by the random pairing model (Fig. 3, Table 1). Surprisingly, this result was obtained even for such cases (chromosome 14, Fig. 2) where the total number of chromosomes associated with nucleoli was variable.

Taken together, our data indicate that the distribution of the NOR-bearing chromosomes among the nucleoli is partly conserved through mitosis.

\section{Conflict of Interest}

There is no conflict of interest.

\section{Acknowledgements}

This work was supported by grants from the Wellcome Trust $075834 / 04 / Z$, the Ministry of Education, Youth and Sports of the Czech Republic MSM0021620806 and LC535, the Grant Agency of Sciences of the Czech Republic AV0Z50110509, and the Grant Agency of the Czech Republic 304/06/1662 and 304/06/1691.

\section{References}

BICKMORE WA, CHUBB JR: Dispatch. Chromosome position: now, where was I? Curr Biol 13: 357-359, 2003.

BUSCH H, SMETANA K: The Nucleolus. Academic Press, New York, 1970.

CREMER T, CREMER C: Chromosome territories, nuclear architecture and gene regulation in mammalian cells. Nat Rev Genet 2: 292-301, 2001.

CREMER T, CREMER C: Rise, fall and resurrection of chromosome territories: a historical perspective Part II. Fall and resurrection of chromosome territories during the 1950s to 1980s. Part III. Chromosome territories and the functional nuclear architecture: experiments and models from the 1990s to the present. Eur J Histochem 50: 223-272, 2006.

ESSERS J, VAN CAPPELLEN WA, THEIL AF, VAN DRUNEN E, JASPERS NG, HOEIJMAKERS JH, WYMAN C, VERMEULEN W, KANAAR R: Dynamics of relative chromosome position during the cell cycle. Mol Biol Cell 16: 769-775, 2005.

FOSTER HA, BRIDGER JM: The genome and the nucleus: a marriage made by evolution. Genome organisation and nuclear architecture. Chromosoma 114: 212-229, 2005.

GERLICH D, BEAUDOUIN J, KALBFUSS B, DAIGLE N, EILS R, ELLENBERG J: Global chromosome positions are transmitted through mitosis in mammalian cells. Cell 112: 751-764, 2003.

HARNIČAROVÁ A, KOZUBEK S, PACHERNÍK J, KREJČI J, BÁRTOVÁ E : Distinct nuclear arrangement of active and inactive c-myc genes in control and differentiated colon carcinoma cells. Exp Cell Res 312: 4019-4035, 2006. 
KALMÁROVÁ M, SMIRNOV E, MAŠATA M, KOBERNA K, LIGASOVÁ A, POPOV A, RAŠKA I: Positioning of NORs and NOR-bearing chromosomes in relation to nucleoli. $J$ Struct Biol 160: 49-56, 2007.

LEUNG AK, GERLICH D, MILLER G, LYON C, LAM YW, LLERES D, DAIGLE N, ZOMERDIJK J, ELLENBERG J, LAMOND AI: Quantitative kinetic analysis of nucleolar breakdown and reassembly during mitosis in live human cells. J Cell Biol 166: 787-800, 2004.

MCCLINTOCK B: The relationship of a particular chromosomal element to the development of the nucleoli in Zea Mays. Z Zellforsch Mikrosk Anat 21: 294-328, 1934.

PARADA L, MISTELI T: Chromosome positioning in the interphase nucleus. Trends Cell Biol 12: 425-432, 2002.

PEDERSON T: The spatial organization of the genome in mammalian cells. Curr Opin Genet Dev 14: 203-209, 2004.

PLISS A, KOBERNA K, VEČEŘOVÁ J, MALÍNSKÝ J, MAŠATA M, FIALOVÁ M, RAŠKA I, BEREZNEY R: Spatio-temporal dynamics at rDNA foci: global switching between DNA replication and transcription. $J$ Cell Biochem 94: 554-565, 2005.

RAŠKA I: Oldies but goldies: searching for Christmas trees within the nucleolar architecture. Trends Cell Biol 13: 517$25,2003$.

RAŠKA I, KOBERNA K, MALÍNSKY J, FIDLEROVÁ H, MAŠATA M: The nucleolus and transcription of ribosomal genes. Biol Cell 96: 579-594, 2004.

SMIRNOV E, KALMÁROVÁ M, KOBERNA K, ZEMANOVÁ Z, MALÍNSKÝ J, MAŠATA M, CVAČKOVÁ Z, MICHALOVÁ K, RAŠKA I: NORs and their transcription competence during the cell cycle. Folia Biol 52: 59-70, 2006.

WALTER J, SCHERMELLEH L, CREMER M, TASHIRO S, CREMER T: Chromosome order in HeLa cells changes during mitosis and early G1, but is stably maintained during subsequent interphase stages. $J$ Cell Biol 160: 685-697, 2003. 